\title{
THE INFLUENCE OF THE GROUNDLAYER STRUCTURE ON THE INVASION OF SMALL BALSAM (IMPATIENS PARVIFLORA DC.) TO NATURAL AND DEGRADED FORESTS
}

\author{
TOMASZ OBIDZIŃSKI, EWA SYMONIDES \\ Department of Plant Ecology and Nature Protection \\ Warsaw University, Aleje Ujazdowskie 4, 00-478 Warszawa, Poland
}

(Received: May 27, 2000. Accepted: September 26, 2000)

\begin{abstract}
Impatiens parviflora DC. was brought to European botanic gardens in 1837, from which it escaped and spread over almost the entire continent colonising predominantly synanthropic habitats. However, in the second half of the 20th century it also became permanently naturalised in natural deciduous forests. The causes of small balsam's success in colonisation of new habitats are not known. They may include either the continuous degradation of forest phytocoenoses or those properties of the alien species that allow it to colonise degraded habitats more effectively as compared to the native species. The aim of this paper was to verify the hypothesis on the relationship between the floristic and structural degradation of the herbaceous or groundlayer and its resistance to the invasion of I. parviflora. The investigations were carried out in the Forest Reserve "Las Bielański" in Warsaw using 30 transects that crossed natural floodplain forests and natural and degraded lime-hornbeam forests. The study has shown that: (1) there is a significant negative correlation between the species richness and cover of the groundlayer and the frequency, cover, and density of the population of I. parviflora; (2) small balsam easily penetrates into degraded and floristically impoverished communities; (3) dense groundlayer of the natural communities provides an effective barrier to the expansion of I. parviflora. This expansion is promoted by such disturbances of the groundlayer that induce formation of gaps providing safe microsites for seed germination and further growth of seedlings.
\end{abstract}

KEY WORDS: Impatiens parviflora, invasion, alien species, synanthropisation, degradation of phytocoenoses.

\section{INTRODUCTION}

Impatiens parviflora DC. (Balsaminaceae), a therophyte of East Asiatic origin, appeared in Europe in 1837 brought as ornamental to the botanical gardens of Dresden and Geneva. In a relatively short time, ca. 150 years, this species spread in Europe, with the exception of the southern part of the continent, colonising diverse habitats from lowland ones to montane deciduous forests (Hegi 1935-1961; Moore 1968; Meusel at al. 1978). By the second half of the 19th century it also became permanently naturalised in natural deciduous forests of Europe (Trepl 1984; Kowarik and Sukopp 1986). In Poland, it changed its status from that of epecophyte to that of holoagriophyte (i.e., neophyte sensu Faliński 1968) during last 30 years (Trzcińska-Tacik 1979; Sudnik-Wójcikowska 1987).

It is not exactly known what-during previous 100 yearsconstituted the barrier preventing I. parviflora to colonise natural plant communities and what are the reasons of its recent success in colonising well-preserved floodplain forests and lime-hornbeam forests, and to some extent beech forests and oak forests (Sudnik-Wójcikowska and Lipka 1992; Świerkosz 1994; Sokołowski 1996, 1997). Similarly to the other alien species, its efficiency as an invader may have the source in declining resistance of forest phytocoenoses caused by anthropogenic disturbance of their structure (Faliński 1966a, b; Kornaś and Medwecka-Kornaś 1986). A connection between biological properties of the invader and its expansion cannot be however excluded, although Binggeli (1996) points to a considerable diversity of life history strategies among invading species. Short life cycle, presence of cleistogamic and chasmogamic flowers, production of a large number of easily germinating seeds, rapid growth of seedlings, and shade tolerance may allow $I$. parviflora to compete successfully with native components of the groundlayer even if the disturbance of the phytocoenosis structure is minor (Goebel 1904; Schemske 1978; Symonides 1987; Perrins et al. 1993).

The aim of this study, being a part of a broader research on the ecology of Impatiens parviflora, was to investigate the relationship between the degree of impoverishment and degradation of forest phytocoenoses and their resistance to invasion of this alien species. In particular, the following hypotheses were falsified:

a) the species richness and degree of structural and floristic disturbance of the groundlayer does not influence the immigration of I. parviflora into the phytocoenosis;

b) the invasion of I. parviflora does not depend on the presence or absence of local disturbance of the biotope.

The investigations were carried out in the "Las Bielański" Reserve in Warsaw, where I. parviflora has been observed for a long time. Despite its small area (ca. 130 hectares), this 
reserve includes relatively natural floodplain forests as well as lime-hornbeam forests, the latter both natural and variously degraded (Solińska-Górnicka and Symonides 1990, 1995). This allows to neglect the possible influence of local climatic conditions on the success of I. parviflora in colonising forest habitats.

\section{METHODS}

The investigations were carried out in the peak of the growing season of 1997 and repeated in 1998 since, for a therophyte, conclusions drawn on the basis of one-year estimation of its frequency and population size may be misleading.

The influence of the structure and degree of naturalness of phytocoenoses on the occurrence and abundance of I. parviflora was investigated in six forest communities that had been previously extensively studied by Solińska-Górnicka and Symonides (1995). Three of these, denoted in the table and figures with numbers from 1 to 3 , represent natural communities: (1) floodplain forest Ficario-Ulmetum campestris and lime-hornbeam forests including (2) Tilio-Carpinetum corydaletosum and (3) Tilio-Carpinetum typicum. The remaining three comprise degraded communities of lime-hornbeam forests: (4) Tilio-Carpinetum corydaletosum with Chelidonium majus and (5) Tilio-Carpinetum typicum with Chelidonium majus that, comparing to natural communities, have more loose tree stand and are floristically impoverished, and (6) Tilio-Carpinetum corydaletosum with the soil enriched with nutrients by faeces of wintering rooks (Solinska-Górnicka et.al. 1997). Investigated patches are cut by footpaths that are $1.5-2 \mathrm{~m}$ and $2.5-3 \mathrm{~m}$ wide in floodplain forests and lime-hornbeam forests, respectively. Along these footpaths more light reaches the groundlayer while trampling of the plant cover is regular.

In each community, five transects were established at the right angle to the footpaths. Each transect comprised 22 squares of $4 \mathrm{~m}^{2}$ each and was divided into three zones representing different intensity of the disturbing factors. Zone A included six squares closest to the footpath where the impact of changed environmental conditions on the footpath should be strongest. Further six squares constituted zone B, in which this impact should be - theoretically - weaker. The remaining ten squares constituted zone $\mathrm{C}$, with the environmental conditions characteristic for the interior of the forest. For each square, the species composition, the number of individuals of I. parviflora and its per cent cover of the ground, and the per cent cover of the remaining species were assessed. Based on these data, for each investigated community, the following indices were calculated: (a) degradation index $d$, expressing the proportion of non-forest species in the floristic composition of the phytocoenosis, (b) mean per cent cover of the ground by the groundlayer species (accompanying I. parviflora), (c) mean percent area of gaps in the groundlayer, including both bare ground and that covered exclusively by I. parviflora, and (d) frequency and density of the population of I. parviflora and its per cent cover of the ground. The mean per cent cover of the ground by the herbaceous-layer species and by $I$. parviflora and the frequency and density of the population of the latter were calculated for the entire transects and for each zone separately.

To evaluate the significance of the differences in the degradation among the zones and the communities, Kruskal-Wallis test and Nemenyi's test were used (Zar 1999). To assess the relationships between the density of the population of $I$. par- viflora and the cover of the ground by other species of the groundlayer, and between the density of the population of $I$. parviflora and the number of species in the groundlayer, correlation coefficients $R$ were calculated using all 660 squares sampled.

\section{RESULTS}

Investigated communities differ significantly one from another with respect to the species richness, the proportion of synanthropic species, and the total cover of the ground by herbaceous and low shrubby species. The groundlayer of relatively natural communities (1-3) has a similar total number of species (20-21), a small number of synanthropic species, and a relatively high ground cover, although diversified with respect to the type of the community. In altered or degraded communities (4-6), the number of species is lower and the proportion of synanthropic species is higher; these include character species for the classes Epilobietea, Artemisietea, and Molinio-Arrhenatheretea. Particularly, the groundlayer in the patch of Tilio-Carpinetum corydaletosum fertilised with faeces of rooks was poor in species and degraded. It comprised only 10 species that, excluding $I$. parviflora, covered only $14-15 \%$ of the ground. Of the only four species characteristic for the class Querco-Fagetea, three occurred with a very low frequency.

The values of the degradation index of the groundlayer are significantly different among the investigated communities and range between $10 \%$ and $50 \%$. The results of the Nemenyi test indicate that among the degraded communities there are two principal groups. The first comprises phytocoenoses of Tilio-Carpinetum corydaletosum and Tilio-Carpinetum typicum, both communities with Chelidonium majus in the groundlayer, while the second includes the patch of Tilio-Carpinetum corydaletosum affected by the population of wintering rooks (Fig. la).

Natural communities also differ from the degraded ones in the proportion of gaps in the herbaceous layer. The per cent area of bare ground and that occupied exclusively by I. parviflora is more diverse among the natural phytocoenoses (1-3) than among degraded ones (4-6) but, for the former, it does not exceed $45 \%$ while, for degraded phytocoenoses, it is not lower than $85 \%$ (Fig. 1b). It is noteworthy that in the natural phytocoenoses the frequency of squares with low values of per cent ground cover $(0-20 \%)$ does not exceed $8 \%$ whereas in disturbed or degraded communities it is always higher than $80 \%$.

The relationship between the degree of degradation of the groundlayer and the occurrence of I. parviflora is apparent: in natural phytocoenoses, the frequency of this neophyte does not exceed $50 \%$, with one exception, whereas in the disturbed and degraded communities it is not less that $80 \%$ (Table 1). Much bigger and statistically significant differences occur in the quantitative characteristics of the population of small balsam. In natural floodplain forests and lime-hornbeam forests, mean cover of the ground by $I$. parviflora is usually lower than $10 \%$ and reaches $16.1 \%$ only in one case. Its population density there is low, ranging between 1.7 and 2.5 individuals per square meter (the differences are statistically insignificant). In degraded lime-hornbeam forests, mean cover of the ground by $I$. parviflora is much higher than that in the natural forests (and not lower than 40.2\%) while its population density is more than 10 times as high as that on the natural forests. Both the cover of the ground and the population den- 

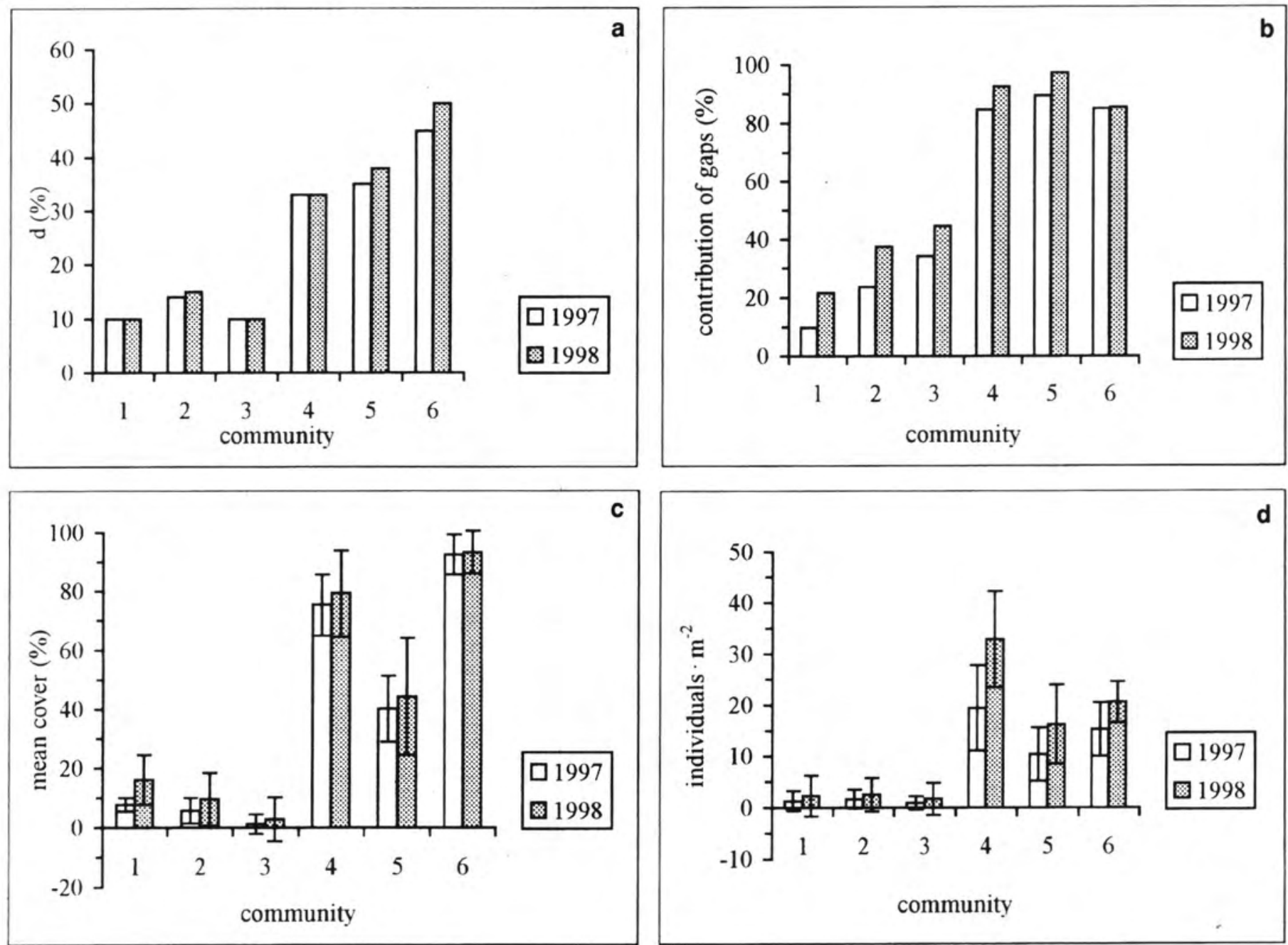

Fig. 1. The influence of the degradation of forest phytocoenoses on the population of Impatiens parviflora. a, proportion (\%) of synanthropic species in the groundlayer; b, area (\%) of gaps in the groundlayer; c, area (\%) covered by I. parviflora; d, population density of $I$. parviflora. Natural communities: 1, Ficario-Ulmetum campestris; 2, Tilio-Carpinetum corydaletosum; 3, Tilio-Carpinetum typicum. Degraded communities: 4, Tilio-Carpinetum corydaletosum with Chelidonium majus; 5, Tilio-Carpinetum typicum with Chelidonium majus; 6, Tilio-Carpinetum corydaletosum on soil fertilised with faeces of roosting birds.

sity were significantly higher $(\mathrm{p}<0.01)$ in the second year of the study than in the first year, for all six communities studied.

The results suggest that these apparent differences in the ground cover and density of the population of $I$. parviflora between natural and degraded communities may diminish in time. Such a scenario is indicated by a significant increase of the frequency of small balsam in the second year as compared to the first year of study and the decrease of the total cover of the ground by other species of the groundlayer, both in the floodplain forest and in the natural patches of lime-hornbeam forest (Table 1).

Based on our results, one cannot conclude which community provides the best growing conditions for $I$. parviflora since, for two communities, 4 and 6 , the frequency of this species was equally high whereas its density was higher in the former and the per cent cover of the ground was higher in the latter (Table 1, Fig. 1c, d). The correlations between the density of $I$. parviflora and the number of its accompanying species as well as their total cover of the ground were negative and statistically significant $(\mathrm{P}<0.001)$. Therefore, the less dense the groundlayer and the less species it has the higher is the population of I. parviflora (Fig. 2a, b). This allows to re- ject the hypothesis that the species richness and degree of structural and floristic disturbance of the groundlayer does not influence the immigration of I. parviflora into the phytocoenosis.

For all communities studied, both natural and degraded, the cover of the ground by the herbaceous-layer species is lowest close to the footpath and increases towards the interior of the forest (Fig. 3a). In contrast, the cover of the ground by I. parviflora and the density of its population decrease with the distance from the footpath (Figs. 3b, c). It is noteworthy that in natural communities I. parviflora occurs almost exclusively in the zone A, i.e., close to the footpath. During the investigations, not a single individual was found inside the forest, i.e., in the zone C. In altered and degraded communities (4-6), small balsam occurs in the entire patch although its density and cover of the ground are always higher close to the footpath than inside the forest. The results of the Nemenyi test show that, for all communities studied and in both years, the density of the population of I. parviflora is significantly higher in the zone A than in the zones B and C. Therefore, the hypothesis that the invasion of I. parviflora does not depend on the presence or absence of local disturbance of the biotope may be rejected. 
TABLE 1. Floristic list and groundlayer cover in forest communities with Impatiens parviflora. 1 - Ficario-Ulmetum campestris, 2 - TilioCarpinetum corydaletosum, 3 - Tilio-Carpinetum typicum, 4 -Tilio-Carpinetum corydaletosum with Chelidonium majus, 5 - Tilio-Carpinetum typicum with Chelidonium majus, 6 - Tilio-Carpinetum corydaletosum fertilised by faeces of roosting birds.

\begin{tabular}{|c|c|c|c|c|c|c|c|c|c|c|c|c|c|}
\hline \multirow{3}{*}{\multicolumn{2}{|c|}{ Species }} & \multicolumn{12}{|c|}{ Community } \\
\hline & & \multicolumn{2}{|c|}{1} & \multicolumn{2}{|c|}{2} & \multicolumn{2}{|c|}{3} & \multicolumn{2}{|c|}{4} & \multicolumn{2}{|c|}{5} & \multicolumn{2}{|c|}{6} \\
\hline & & 1997 & 1998 & 1997 & 1998 & 1997 & 1998 & 1997 & 1998 & 1997 & 1998 & 1997 & 1998 \\
\hline $\mathrm{AP}$ & Circaea lutetiana & 44 & 48 & & & & & & & & & & \\
\hline $\mathrm{AP}$ & Prunus avium & 4 & 4 & & & & & & & & & & \\
\hline QF & Fraxinus excelsior & 4 & 4 & & & & & & & & & & \\
\hline QF & Ranunculus lanuginosus & 16 & 18 & & & & & & & & & & \\
\hline \multirow[t]{9}{*}{$\mathrm{QF}$} & Paris quadrifolia & 4 & 4 & & & & & & & & & & \\
\hline & Rubus caesius & 20 & 24 & & & & & & & & & & \\
\hline & Stellaria nemorum & 28 & 30 & & & & & & & & & & \\
\hline & Ulmus laevis & 4 & 4 & & & & & & & & & & \\
\hline & Alnus glutinosa & 2 & 2 & & & & & & & & & & \\
\hline & Cornus sanguinea & 4 & 4 & & & & & & & & & & \\
\hline & Crataegus monogyna & 2 & 2 & & & & & & & & & & \\
\hline & Viburnum opulus & 8 & 8 & & & & & & & & & & \\
\hline & Geum urbanum & 4 & 4 & 2 & 2 & & & & & & & & \\
\hline AP & Stachys sylvatica & 40 & 40 & 20 & 20 & & & & & & & & \\
\hline \multirow[t]{3}{*}{ QF } & Aegopodium podagraria & 84 & 86 & 36 & 32 & & & 4 & 4 & & & & \\
\hline & Glechoma hederacea & 16 & 16 & 8 & 8 & & & & & & & & \\
\hline & Impatiens parviflora $\mathrm{T}$ & 26 & 48 & 50 & 60 & 12 & 27 & 100 & 100 & 80 & 88 & 100 & 100 \\
\hline \multirow{2}{*}{ QF } & Galeobdolon luteum & 96 & 96 & 100 & 100 & 96 & 98 & 24 & 22 & 12 & 10 & 40 & 36 \\
\hline & Oxalis acetosella & 8 & 10 & 56 & 56 & 20 & 24 & 24 & 24 & & & 8 & 8 \\
\hline $\mathrm{Ar}$ & Urtica dioica & 4 & 12 & 2 & 4 & & & & & 12 & 12 & 6 & 10 \\
\hline $\mathrm{QF}$ & Viola sylvestris & & & 16 & 16 & & & 32 & 28 & 20 & 18 & 8 & 7 \\
\hline $\mathrm{C}$ & Carpinus betulus & & & 36 & 30 & 84 & 84 & 46 & 40 & 14 & 12 & & \\
\hline \multirow[t]{3}{*}{ QF } & Acer platanoides & & & 20 & 20 & 32 & 28 & 8 & 8 & 20 & 20 & & \\
\hline & Majanthemum bifolium & & & 36 & 38 & 64 & 64 & 12 & 10 & 6 & 6 & & \\
\hline & Quercus robur & & & 20 & 20 & 2 & 2 & 36 & 36 & & & 8 & \\
\hline QF & Milium effusum & & & 16 & 20 & 8 & 10 & & & & & 4 & 4 \\
\hline $\mathrm{C}$ & Stellaria holostea & & & 32 & 34 & 30 & 30 & & & & & 4 & 4 \\
\hline $\mathrm{C}$ & Cerasus avium & & & 24 & 18 & 8 & 6 & & & & & & \\
\hline QF & Acer pseudoplatanus & & & 8 & 8 & & & & & & & & \\
\hline QF & Pulmonaria obscura & & & 28 & 28 & & & & & & & & \\
\hline \multirow[t]{2}{*}{ QF } & Asarum europaeum & & & 4 & 4 & & & & & & & & \\
\hline & Lamium maculatum & & & 16 & 14 & & & & & 12 & 14 & & \\
\hline \multirow[t]{2}{*}{ QF } & Melica nutans & & & & & 2 & 2 & & & & & & \\
\hline & Sorbus aucuparia & & & & & 2 & 2 & & & & & & \\
\hline \multirow[t]{2}{*}{ QF } & Euonymus europaeus & & & & & 4 & 4 & 4 & 4 & & & & \\
\hline & Geranium robertianum $\mathrm{T}$ & & & & & 14 & 14 & 16 & 16 & 32 & & & \\
\hline QF & Poa nemoralis & & & & & 40 & 40 & & & 16 & 17 & & \\
\hline & Convallaria majalis & & & & & 16 & & & & 16 & 18 & & \\
\hline & Galeopsis pubescens T & & & & & 8 & 12 & & & 16 & 19 & & \\
\hline & Moehringia trinervia $\mathrm{T}$ & & & & & 6 & & & & 24 & 24 & & \\
\hline & Galium aparine $\mathrm{T}$ & & & & & 32 & 26 & & & 40 & 44 & & \\
\hline $\mathrm{Ar}$ & Chelidonium majus & & & & & & & 8 & 9 & & & & \\
\hline MA & Poa trivialis & & & & & & & 6 & 6 & & & & \\
\hline & Quercus rubra & & & & & & & 8 & 8 & & & & \\
\hline & Sambucus nigra & & & & & & & 36 & 40 & 8 & 10 & 80 & 85 \\
\hline MA & Plantago lanceolata & & & & & & & & & 2 & 3 & & \\
\hline & Stellaria media $\mathrm{T}$ & & & & & & & & & 36 & 38 & & \\
\hline & Polygonum lapathifolium ssp. incanum $\mathrm{T}$ & & & & & & & & & & & 4 & 4 \\
\hline MA & Rumex acetosa & & & & & & & & & & & 4 & 6 \\
\hline & Number of individuals & 20 & 20 & 21 & 20 & 20 & 20 & 15 & 15 & 17 & 16 & 11 & 10 \\
\hline & Herb layer cover $(\%)$ & 90.2 & 78.3 & 74.3 & 62.6 & 68.5 & 55.4 & 15.3 & 7.5 & 10.5 & 2.8 & 15 & 14.5 \\
\hline
\end{tabular}

Characteristic species: AP - Alno-Padion, C - Carpinion, QF - Querco-Fagetea + Fagetalia, MA - Molinio-Arrhenatheretea, Ar - Artemisietea, Ea Epilobietea angustifolii, T - therophyte

\section{DISCUSSION}

In Warsaw, Impatiens parviflora was recorded for the first time by Kamieński (1884) who found a large population of this species in the Botanic Garden of Warsaw University and in the adjacent Łazienki Park. Therefore, similarly as in other European cities, small balsam may have been brought to the Botanic Garden and these plants were the source of diaspores 

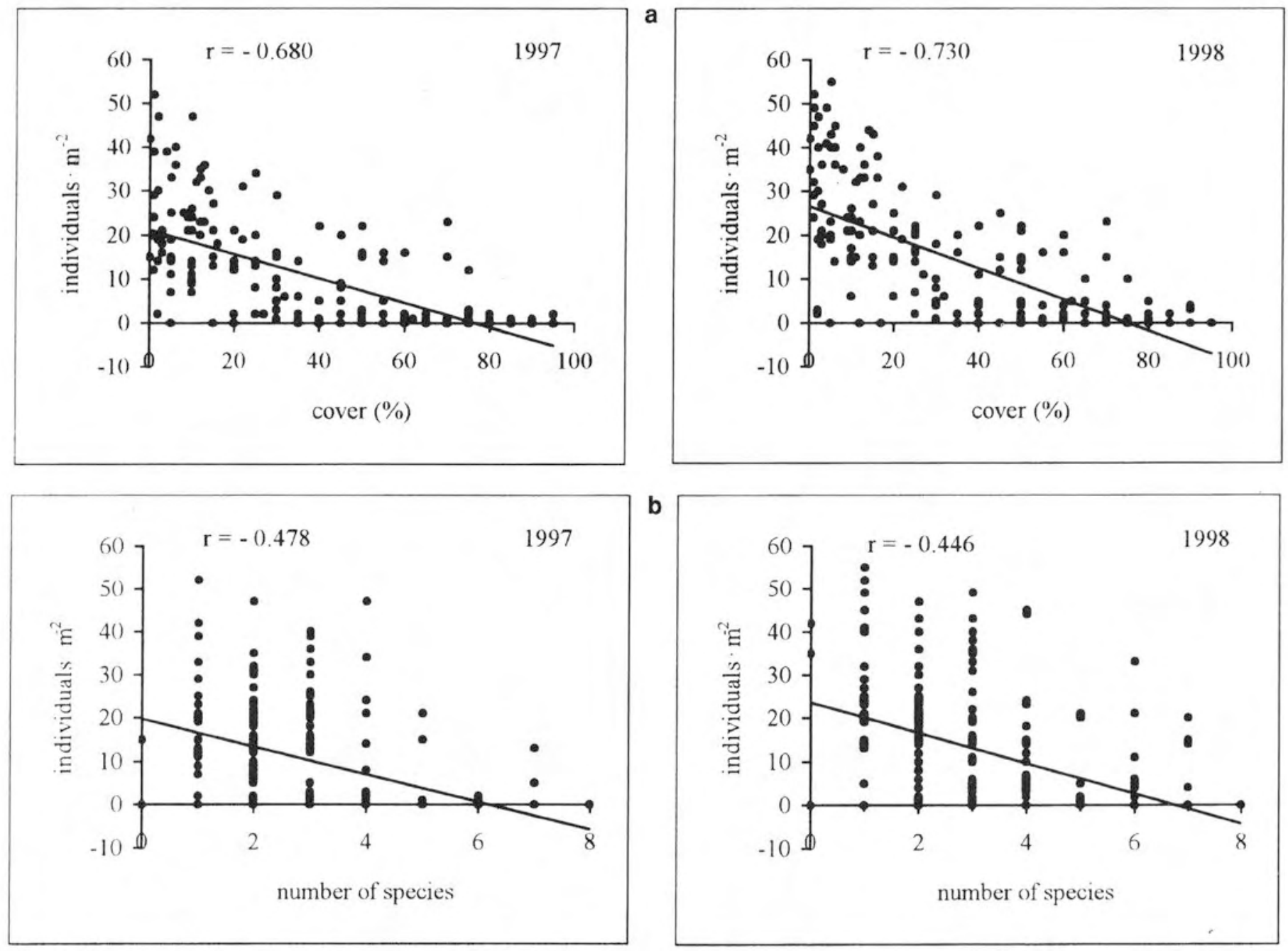

Fig. 2. The relationship between population density of Impatiens parviflora and (a) cover of the ground by other herbaceous species of the groundlayer, and (b) the number of species in the groundlayer $(\mathrm{N}=660, \mathrm{P}<0.001)$.

that gave rise to the wild populations of this species. It is noteworthy that I. parviflora was neither found by Rostafiński (1873) nor by Łapczyński (1882) in his study of "gains" and "losses" of the flora of Warsaw and its surroundings. Between 1900 and 1945, only four localities of this species were known, seven were recorded during next 25 years while between 1977 and 1996 this species had 80 localities including some in natural communities or those weakly altered by human activity (Grochowski 1932, Sudnik-Wójcikowska 1987, 1992, 1998).

The studies describing the naturalisation of I. parviflora in natural floodplain forests, lime-hornbeam forests, beech forests and oak forests (cited in the introduction to this paper) suggest that small balsam is a very aggressive coloniser of new habitats and it presumably eliminates native elements of the groundlayer as do many other invasive alien species (Daumann 1967, Meeking and McCarthy 1999, Willis and Blossey 1999). This may seem contradictory to the conclusions drawn from this study that in natural floodplain forests and lime-hornbeam forests there is an effective barrier for the invasion of small balsam. However, one must note that phytogeographic, floristic, and phytosociological studies use a different space scale than that used in plant population studies. The latter are usually based on observations from small per- manent plots. A significant relationship between local disturbances of the biotope and groundlayer structure and the occurrence of small balsam may have not been therefore noticed in these large-scale studies.

The results of this study unequivocally demonstrate that species-rich natural forest communities are much more resistant to the invasion of $I$. parviflora than those degraded and altered by human activity. Such a conclusion was also drawn from other studies of alien invasive species (Elton 1958; Case 1990; Sudnik-Wójcikowska 1998). Although the appearance of an invasive neophyte in the phytocoenosis contributes to its further degradation, but presumably it is always promoted by previous disturbances of the phytocoenosis and its biotope (Faliński 1966a, b; Gordon 1998; Anderson 1999). The immediate causes of the disturbances fostering invasion of alien species, i.e, a low density of the groundlayer and its floristic impoverishment, are not that important. They comprise both natural events, including fallen trees and overgrazing by native herbivores, and direct or indirect human impact, including logging, ecosystem fragmentation by roads, trampling, and grazing by domestic animals (Pyšek and Pyšek 1991; Kowarik 1996). Our results fully confirm this connection: I. parviflora is abundant not only in degraded communities but also in disturbed zones adjacent to footpaths crossing natural com- 

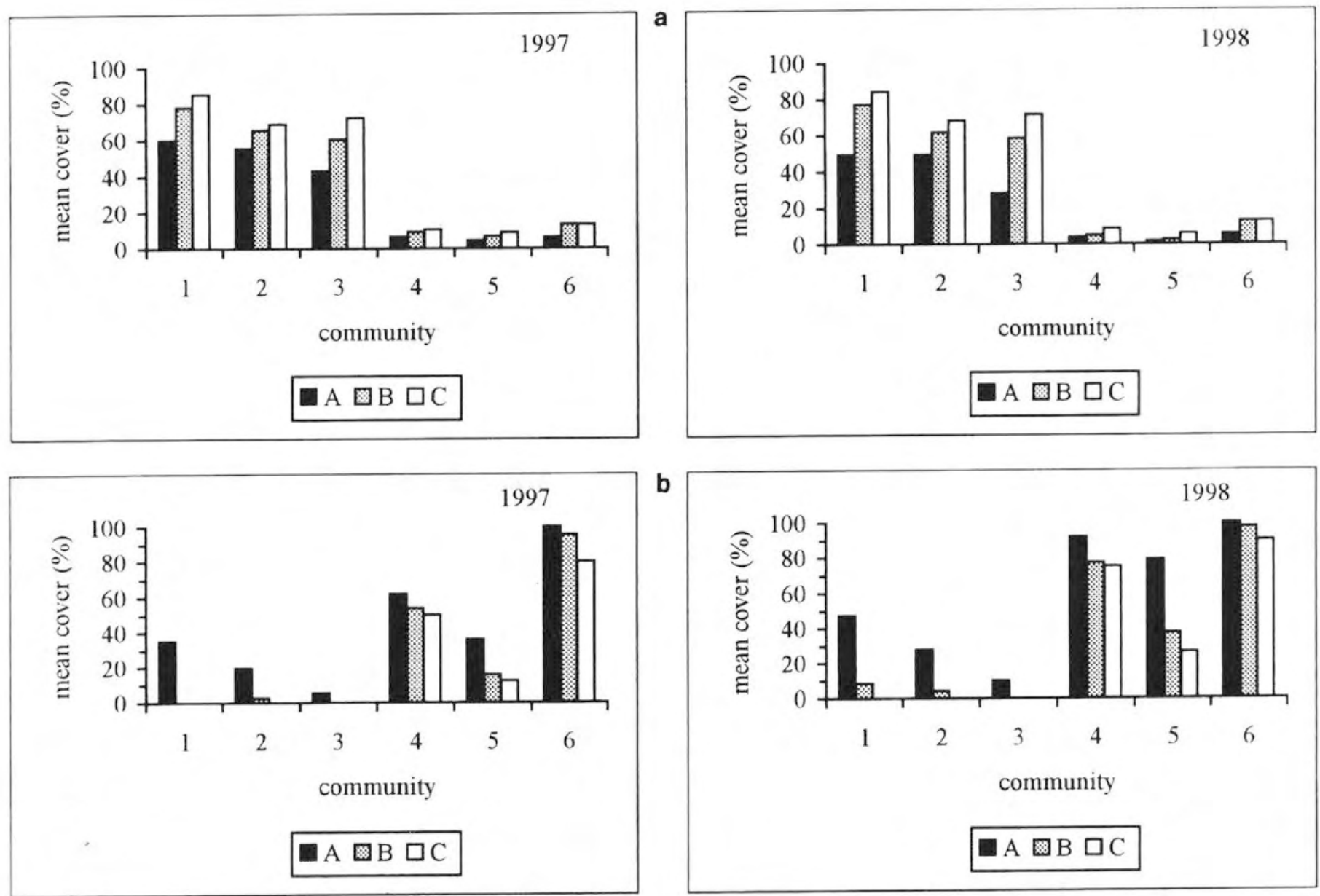

b
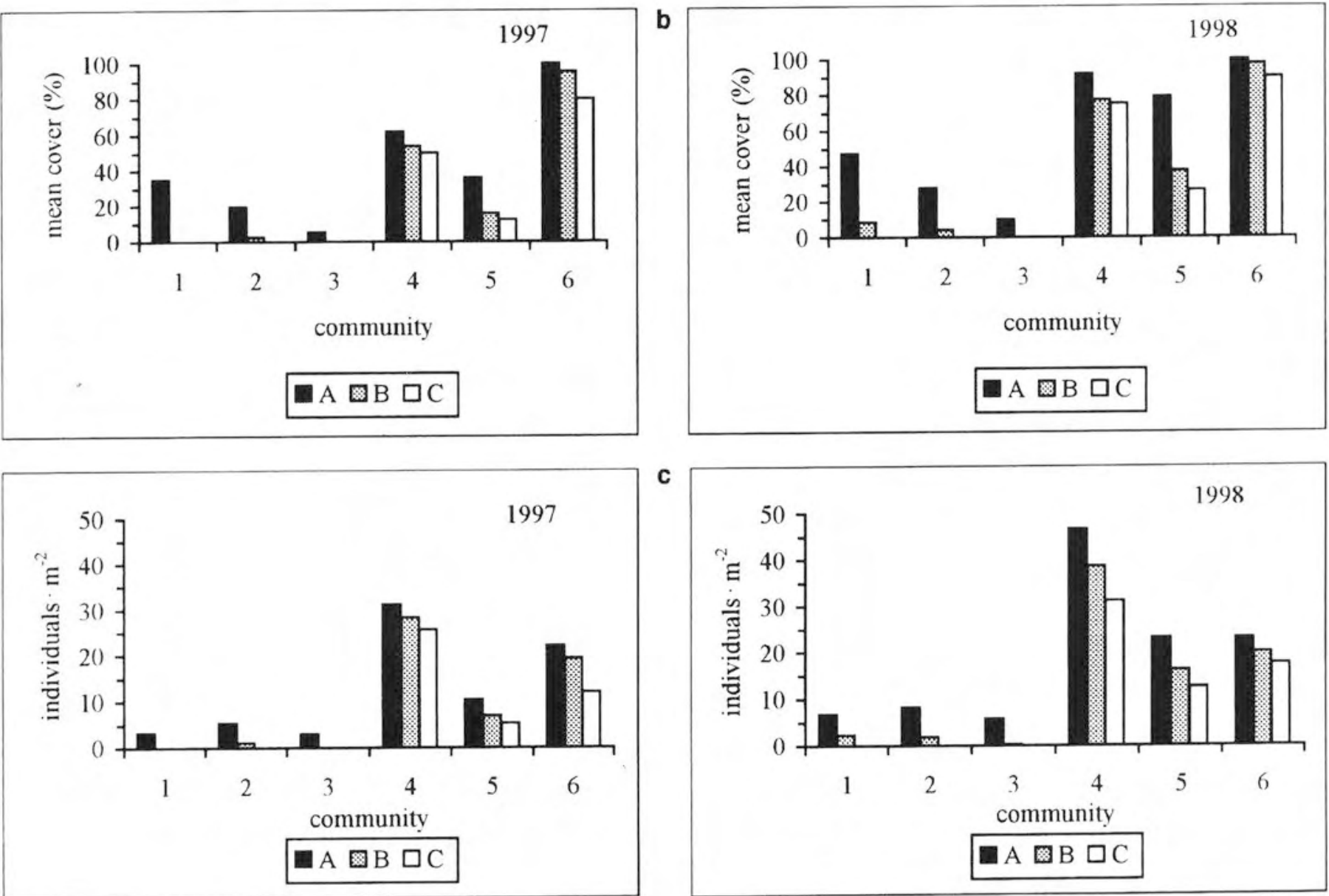

Fig. 3. The influence of the disturbed biotope conditions and the degradation of the groundlayer on the population of Impatiens parviflora. a, mean cover $(\%)$ of the groundlayer; b, mean cover (\%) of Impatiens parviflora; c, population density of 1 . parviflora. The communities are the same as in Fig. 1. Transects were divided into zones on the basis of the distance from the footpath, which is $0-12$, 12-24, and 24-44 for zones $\mathrm{A}, \mathrm{B}$, and $\mathrm{C}$, respectively.

munities. The invasion of this neophyte is therefore facilitated both by better availability of light due to the less dense tree canopy, the mechanical destruction of the groundlayer due to trampling by strollers, and the fertilisation of the soil by faeces of roosting birds. Such a conclusion is supported by the comparison of the cover of the ground by herbaceous and low shrubby species and the density and cover of I. parviflora in the three zones of the transects that were distinguished on the basis of distance from the footpath.
The "Las Bielański" Reserve is located a mere six kilometres from the historic centre of Warsaw. It has been formally protected since 1974 but for over a hundred years it has been a favourite place for weekend recreation of the citizens of Warsaw. It is not surprising therefore that within its borders there are not any forest communities that are fully natural and exempt from human impact; a dense net of roads and footpaths accelerates its degradation (Faliński 1961, 1973; Solińska-Górnicka and Symonides 1990, 1995). The majority of synanthropic species, including Plantago major and Poa annua, 
do not reach inside the forest and are confined to the footpaths and their vicinity. Others, including Taraxacum officinale and Stellaria media, enter only into much degraded forest characterised by loose tree stand and poor groundlayer (Solińska-Górnicka and Symonides 1994). For I. parviflora, the interior of natural forests, that is undisturbed and not affected by changed biotope conditions, is inaccessible: not a single individual was found in the zone $\mathrm{C}$ of the floodplain forests and the lime-hornbeam forests.

In its native East Asia, I. parviflora occurs along rivers and streams, in shady and humid localities (Komarov 1934-1964). In Europe, it prefers mildly acid or neutral mineral-organic soils in half-shaded places and should be therefore more abundant inside the forest than at its outskirts or along the footpaths (Hughes and Evans 1962; Hughes 1965; Zarzycki 1984; Sudnik-Wójcikowska 1987). The fact that it does not enter any of the natural communities in the Bielany Forest indicates that the dense groundlayer of these communities provides a sufficient barrier for the expansion of this neophyte.

Numerous studies suggest that the establishment of an alien annual species depends on the number of safe microsites for seed germination (Jouret 1974; Harper 1990; Thompson and Hodgson 1995). In a dense, lush groundlayer, there is not enough free space necessary for simultaneous germination of seeds and further growth of a cluster of seedlings what seems to be crucial for forest therophytes (Smith 1983; Winsor 1983). The disturbances in the groundlayer that loosen its dense herbaceous vegetation and create gaps in the forest floor are necessary for the maintenance of the population of such species, the more that these species do not reproduce asexually and particularly if their seeds are dispersed at small distance (Grubb 1977; Bolker and Pacala 1999). A much higher density of $I$. parviflora in disturbed communities than in those relatively natural unequivocally shows that the success of invasion of an alien species depends on the degree of disturbance of the structure of the invaded community (Rejmánek 1989).

Despite those natural barriers, I. parviflora will undoubtedly be more and more abundant in natural communities. In the second year of the investigations, its frequency, density and cover were higher than in the first year. Additionally, some individuals appeared in the zones B of some phytocoenoses in which this species had been confined to zones A a year before. It is therefore possible that I. parviflora is capable of competitive exclusion of its immediate neighbours, similarly as it excludes its cousin I. noli-tangere (Daumann 1967). It is not known whether this process may also occur inside the natural forest communities since, during two years of this study, not a single individual of small balsam appeared in the zone C. Some data indicate that clusters of individuals of $I$. parviflora may emerge inside natural forests in hollows left by windfallen uprooted trees but do not persist there. These gaps are soon taken over by forest perennials that reproduce asexually and exclude therophytes, sometimes even mechanically destroying fragile individuals of small balsam. In dense forest communities, I. parviflora is therefore not able to compete successfully for space, the main factor limiting plant growth and development (Yodzis 1978).

In conclusion, the results of this study allow to reject the hypothesis that there is no significant relationship between the degree of degradation of forest phytocoenoses and their resistance to the invasion of $I$. parviflora. They also suggest that in the natural communities that are characterised by a dense groundlayer with many species, I. parviflora may emerge only ephemerally.

\section{LITERATURE CITED}

ANDERSON R. 1999. Disturbance as a factor in the distribution of sugar maple and the invasion of Norwey maple into a modified woodland. Rhodora 101: 264-273.

BINGGELI P. 1996. A taxonomic, biogeographical and ecological overview of invasive woody plants. J. Veg. Sci.: 7:121-124.

BOLKER B.M., PACALA S.W. 1999. Spatial moment equations for plant competition: understanding spatial strategies and the advantages of short dispersal. Am. Nat. 153: 575-602.

CASE T.J. 1990. Invasion resistance arises in strongly interacting species-rich model competition communities. Proc. Nat. Acad. Sci. USA 87: 9610-9614.

DAUMAN E. 1967. Zur Bestäubungs-und Verbreitungsökologie dreier Impatiens - Arten. Preslia 39: 43-58.

ELTON C.S. 1958. The Ecology of Invasion by Animals and Plants. Methuen, London, pp. 181.

FALIŃSKI J.B. 1961. Roślinność dróg leśnych w Białowieskim Parku Narodowym. Acta. Soc. Bot. Pol. 30: 163-185. (in Polish)

FALIŃSKI J.B. 1966a. Próba określenia zniekształceń fitocenozy. System faz degeneracyjnych zbiorowisk roślinnych. Ekol. Pol. Ser. B 12: $31-42$.

FALIŃKI J.B. 1966b. Degeneracja zbiorowisk roślinnych Lasu Miejskiego w Iławie. Mater. Zakł. Fitosocjol. Stos. UW 13: 1-13.

FALIŃSKI J.B. 1968. Stadia neofityzmu i stosunek neofitów do innych komponentów zbiorowiska. Mater. Zakł. Fitosocjol. Stos. UW 25: 15-31.

FALIŃSKI J.B. 1973. Reakcja runa leśnego na wydeptywanie w świetle badań eksperymentalnych. Phytocoenosis 3: 205-220.

GOEBEL K. 1904. Die kleistogamen Blüten and die Anpassungstheorien. Biol. Zentralbl. 24: 673-697.

GORDON D.R. 1998. Effects of invasive, non-indigenous plant species on ecosystem processes: lessons form Florida. Ecol. Appl. 8: 975-989.

GROCHOWSKI W. 1931. Flora Wilanowa i okelic. Wiad. Farmac. 15: 5-61.

GRUBB P.J. 1977. The maintenance of species-richness in plant communities the importance of the regeneration niche. Biol. Rev. 52: 107-145.

HARPER J.L. 1990. Population Biology of Plants. Academic Press, London, pp. 892.

HEGI G. 1935-1961. Illustrierte Flora von Mittel-Europa. C. Hansen Verl., München.

HUGHES A.P. 1965. Plant growth and the aerial environmental. VII. The growth of Impatiens parviflora in very low light intensities. New Phytol. 64: 55-64.

HUGHES A.P., EVANS G.C. 1962. Plant growth and the aerial environment. II. Effects of light intensity on Impatiens parviflora. New Phytol. 61: 154-174.

JOURET M.F. 1974. Quelques aspects écologiques de la dormance et de la germination chez Impatiens parviflora D. C. Bull. Soc. R. Bot. Belg. 107: 323-340.

KAMIEŃSKI F. 1884. Nowy nabytek flory krajowej. Wszechświat 3: 517-518.

KOMAROW W.L. (ed.). 1934-1964. Flora SSSR, 1-30. Izdat. A. N. SSSR, Leningrad.

KORNAŚ J., MEDWECKA-KORNAŚ A. 1986. Geografia roślin. PWN, Warszawa, pp.

KOWARIK I. 1990. Some responses of flora and vegetation to urbanization in Central Europe. In: Urban ecology. Plants and plant communities. Sukkop H., Hejný S. (ed.). SPB Academic Academic Publ., The Hague, pp. 113-129.

KOWARIK I. 1996. On the role of alien species in urban flora and vegetation. In: Plant invasions: General aspects and special problems. Pyšek P., Prach K., Rejmánek M. and Wade M. (eds.). SPB Academic Publ., Amsterdam, pp. 85-103.

ŁAPCZYŃSKI K. 1882. O roślinności jawnokwiatowej okolic Warszawy. Pam. Fizyjogr. 2: 327-347.

MEEKINS J.F., McCARTHY B.C. 1999. Competitive ability of Alliaria petiolata (garlic mustard, Brassicaceae), an invasive, nonindigenous forest herb - Inter. J. Plant Sci. 160: 743-752. 
MEUSEL H., JÄGER E., RAUSCHERT S., WEINERT E. 1978. Vergleichende Chorologie der zentraleuropäischen Flora. Veb Gustav Fischer Verlag, Jena, pp. 1-421.

MOORE D.M. 1968. Impatiens L. In: Flora Europaea, I-IV. Tutin T. G. et al. (eds.). Univ. Press, Cambridge.

PYŠEK P., PYŠEK A. 1991. Succession in urban habitats: an analysis of phytosociological data. Preslia 63: 125-138.

REJMÁNEK M. 1989. Invasibility of plant communities. In: Biological invasion: a global perspective. Drake J.A. et al. (eds.). SCOPE, Hohn Wiley and Sons LTD., pp.

ROSTAFIŃSKI F. 1873. Florae Polonicae Prodromus. R. Friedländer and Sohn, Berlin, ss.

SCHEMSKE D.W. 1978. Evolution of reproductive characteristics in Impatiens (Balsaminaceae): the significance of cleistogamy and chasmogamy. Ecology 59: 596-613.

SMITH B.H. 1983. Demography of Floerkea proserpinacoides, forestfloor annual. III. Dynamics of seed and seedling populations. J. Ecol. 71: 413-425.

SOKOŁOWSKI A. 1996. Roślinność rezerwatu "Antoniuk" koło Białegostoku. Par. Nar. Rez. Przyr. 15: 23-40.

SOKOŁOWSKI A. 1997. Roślinność rezerwatu "Las Zwierzyniecki" w Białymstoku. Par. Nar. Rez. Przyr. 16: 3-9.

SOLIŃSKA-GÓRNICKA B., NAMURA-OCHALSKA A., SYMONIDES E.1996. Long-term dynamics of a relict ancient forest in an urban area. Fragm. Flor.Geobot. 42: 423-474.

SOLIŃSKA-GÓRNICKA B., SYMONIDES E. 1990. Effect of a major city on the structure of coenoelements in a natural woodland in Warsaw. Vegetatio 88: 163-176.

SOLIŃSKA-GÓRNICKA B., SYMONIDES E. 1994. The adverse influence of footpaths upon natural vegetation in protected forests. In: Applied Vegetation Ecology. Song Y., Dierschke H., Wang K. (eds.). East Cina Normal Univ. Press, Shanghai, pp. 96-107.

SOLIŃSKA-GÓRNICKA B., SYMONIDES E. 1995. Synanthropization of forest vegetation as a result of urban pressure. In: Functio- ning and dynamics of natural and perturbed ecosystems. Bellan D., Bonin G., Emig C. (eds.) Lavoisier Publ., Paris, pp. 516-533.

SUDNIK-WÓJCIKOWSKA B.. 1987. Flora miasta Warszawy i jej przemiany w ciągu XIX i XX wieku. I. Wyd. Uniwersytetu Warszawskiego, Warszawa, pp. 242.

SUDNIK-WÓJCIKOWSKA B. 1998. Czasowe i przestrzenne aspekty procesu synantropizacji flory na przykładzie wybranych miast środkowej Europy. Wyd. Uniwersytetu Warszawskiego, Warszawa, pp. 167.

SUDNIK-WÓJCIKOWSKA B. and LIPKA J. 1992. Flora rezerwatu "Las Kabacki" w Warszawie, walory i zagrożenie. Parki Nar. Rez. Przyr. 11: 49-58.

SYMONIDES E. 1987. Strategia reprodukcyjna terofitów, mity i fakty. II. Amfikarpia i ewolucja strategii "pesymistycznej". Wiad. ekol. 33: 137-160.

ŚWIERKOSZ K. 1994. Zbiorowiska roślinne Góry Chojnik - eksklawy Karkonoskiego Parku Narodowego. Par. Nar. Rez. Przyr. 13: 17-36.

THOMPSON K., HODGSON J.G., RICH T.C.G. 1995. Native and alien invasive plants: more of the same? Ecography 18: 390-402.

TREPL L. 1984. Über Impatiens parviflora D.C. Als Agriophyt in Mitteleuropa. Diss. Bot. 73: 1-400.

TRZCIŃSKA-TACIK H. 1979. Flora synantropijna Krakowa. Rozpr. habil. UJ 32, pp. 278.

WILLIS A.J., BLOSSEY B. 1999. Benign environments do not explain the increased vigour of non-indigenous plants: a cross-continental transplant experiment. Bio. Sci. Tech. 9: 567-577.

WINSOR J. 1983. Persistence by habitat dominance in the annual $/ \mathrm{m}$ patiens capensis (Balsaminaceae). J. Ecol. 71: 451-466.

YODZIS P. 1978. Competition for space and structure of ecological communities. Springer Verlag, Berlin.

ZAR J. H. 1999. Biostatistical analysis. Prentice Hall Inc., New Jersey, pp.

ZARZYCKI K. 1984. Ekologiczne liczby wskaźnikowe roślin naczyniowych Polski. Instytut Botaniki PAN, Kraków, pp.

\section{WPEYW STRUKTURY RUNA \\ NA WNIKANIE NIECIERPKA DROBNOKWIATOWEGO (IMPATIENS PARVIFLORA DC.) DO NATURALNYCH I ZDEGENEROWANYCH FITOCENOZ LEŚNYCH}

\section{STRESZCZENIE}

Impatiens parviflora DC. sprowadzono do ogrodów botanicznych Europy w 1837 roku, z których - jako uciekinier - rozprzestrzenił się na niemal całym kontynencie, głównie na siedliskach synantropijnych (Moore 1968; Meusel et al. 1978). W drugiej połowie XX wieku zyskał status gatunku trwale zadomowionego także w naturalnych lasach liściastych (Trepl 1984; Kowarik and Sukopp 1986; Sudnik-Wójcikowska 1987). Przyczyny sukcesu niecierpka drobnokwiatowego, jako kolonizatora nowych siedlisk, nie są znane. Jego źródłem może być postępująca degeneracja zbiorowisk leśnych, ale może także wynikać z takich cech obcego przybysza, dzięki którym skuteczniej zdobywa tereny zaburzone w porównaniu z gatunkami rodzimymi (por. Binggeli 1996; Anderson 1999).

W pracy postawiono hipotezę o braku istotnej zależności między stopniem florystycznej i strukturalnej degeneracji runa fitocenoz leśnych a ich odpornością na inwazję I. parviflora. Badania przeprowadzono w rezerwacie leśnym "Las Bielański" w Warszawie na 30 transektach przecinających naturalne łęgi oraz naturalne i zdegenerowane grądy. Wykazano: (1) istotną, ujemną korelację między bogactwem gatunkowym i pokrywaniem runa a frekwencją, pokrywaniem i zagęszczeniem populacji I. parviflora, (2) swobodną penetrację I. parviflora do wnętrza zbiorowisk florystycznie zubożonych i przekształconych, oraz (3) występowanie naturalnej bariery dla ekspansji $I$. parviflora w zwartym runie zbiorowisk naturalnych. Badania dowiodły, że warunkiem okupowania przez I. parviflora zbiorowisk naturalnych są takie zaburzenia runa, wskutek których na dnie lasu powstają luki, spełniające rolę "bezpiecznych miejsc do kiełkowania" nasion i wzrostu siewek (sensu Harper 1990).

SŁOWA KLUCZOWE: Impatiens parviflora, gatunek inwazyjny, gatunek obcy, synantropizacja, degeneracja fitocenoz. 